\title{
Assessing China's Long Term Export and Income Growth in the Global Markets
}

\author{
Agapi Somwaru ${ }^{1}$, Francis Tuan ${ }^{2} \&$ Sun Ling Wang ${ }^{3}$ \\ ${ }^{1}$ Economic Consulting, USA and East Asia Economic Consulting, Washington DC, USA \\ ${ }^{2}$ Visiting Lecturer Professor, School of Agricultural Economics and Rural Development, Renmin University, \\ Beijing, China, and East Asia Economic Consulting, USA \\ ${ }^{3}$ Economist, Economic Research Service, U.S. Department of Agriculture, Washington DC, USA \\ Correspondence: Agapi Somwaru, Ph.D., 607 Hawkesbury Lane, Silver Spring, Maryland 20904, USA. Tel: \\ 1-301-622-6967. E-mail: agapi.somwaru@gmail.com
}

Received: July 21, 2018

doi:10.5539/ijef.v10n9p98
Accepted: August 10, $2018 \quad$ Online Published: August 20, 2018

URL: https://doi.org/10.5539/ijef.v10n9p98

\begin{abstract}
This paper delves into China's differential growth in exports with high income and developing countries by focusing on bilateral content of China's trade and particular exports over the time period 1979-2015. In the last 30 plus years, China has specialized in upstream capital goods and exhibited rapid diversification in consumer goods. Performing causality tests reveals a strong evidence of causality from the export growth of capital goods and consumer non-durable goods to gross domestic product (GDP) per capita. There is also evidence that the causality is bi-directional for consumer durable goods, intermediate goods, and primary non-energy goods with income. Econometric analysis shows a positive and statistical significant relationship between income and export growth of capital goods, consumer non-durable goods, intermediate goods, and primary non-energy goods. Trade openness allows stimulation of growth and efficiency as producers in China are exploiting areas in which they have a comparative advantage.
\end{abstract}

Keywords: trade, export growth, causality, income growth

\section{Introduction}

\subsection{Issues and Objectives}

Many studies highlight a strong positive correlation between the exporting goods a country produces and its living standard (Hummels \& Klenow, 2005). Linder (1961) suggests that the level of income per capita might have a role in explaining increased trade and especially international differences in demand for various tradable goods. Markusen (1986) states that as income levels rise spending patterns shift towards manufacturing products that are associated with more sophisticated production processes. Rose (1991), Baier and Bergstrand (2001) also indicate that as a country's income rises consumers tend to shift their spending away from basic food and clothing products into manufacturing goods, which are associated with product differentiation and diversification. Since initiating market reforms in 1978, China has entered a new growth phase in its industrial development for producing and exporting consumer and technology goods while experiencing higher incomes. Building upon these hypotheses and findings from the literature, this study seeks to analyze the relationship between China's export growth and income growth progression for the period of 1979 through 2015 . We empirically evaluate the causality between growth in trade, especially in exports, and China's overall economic growth. Specifically, we attempt to assess export growth as a contributing factor to China's economic growth, which is measured by its per capita income.

At the core of these assessments are the related questions that whether China's overall growth in international trade can (1) be viewed as an amplified reaction to the country's overall economic growth, (2) how significantly this growth in exports has reacted to changes in China's economic growth, and (3) what is the role of the country's policy interventions in this exports-growth nexus.

This study addresses these issues by examining China's export growth path from 1979 through 2015, analyzing the impact of export growth on China's economic growth, and evaluating the effects of the adoption of policies of preferential tariff treatment on China's export growth. 


\subsection{Hypotheses and Inferences}

We measure and assess the dynamics of growth in exports and obtain insights into China's export diversification and exceptional growth. We apply both parametric and non-parametric methods to empirically estimate the effect of export growth on income measured by China's per capita GDP.

This paper presents China's underlying long-term trends in the growth of its exports. One main finding is that China's strong downstream production can be associated with selective policies that granted preferential tariff treatment to assembling and processing activities (generated by foreign direct investment (FDI)). The result of this policy-induced specialization is captured by rapid diversification in consumer goods. The study suggests that export growth has a quantitatively robust statistically significant and positive effect on income. China's trade openness has stimulated economic growth and efficiency. The statistical significance of China's trade policy on economic growth is in agreement with prior knowledge, which is based upon economic growth theory.

\section{Method}

China's intertemporal exports growth is assessed to demonstrate the unique inquiry of China's export and income growth nexus. Consequently, the methodology is presented that attempts to analyze and test the underlying forces of exports and income growth over time. For this purpose, we specify and utilize non-parametric tests. We also identify and apply formal parametric econometric methodologies to evaluate export growth and income.

\subsection{China's Exports and Intertemporal Growth}

China's low-cost labor has enhanced a vast step forward in global trade. The Chinese share of global exports topped $11 \%$, with trade accounting for more than half of the country's GDP. China competes world-wide in exporting goods of low labor cost and increased availability (in quantity) (Subramanian \& Kessler, 2013). Due to its proximity to capital-abundant East Asian economies, China has an advantage to the rapidly growing Asia-Pacific markets' increased demand. A growing literature has attempted to determine whether neighborhood trade is explained mainly by natural factors, such as geographic proximity. Several studies, e.g., Deardorff and Stern (1994), Engel and Rogers (1996), Stein and Frankel (1994), Frankel (1996, 1997), Frankel et al. (1996, 1999), and Parsley and Wei (1996) find strong linkages between bilateral trade and the proximity of trading partners, where proximity is represented by distance, adjacency, and common language to reflect cultural similarities. Geographic proximity and cultural similarity may explain why neighboring countries trade disproportionately but they provide little insight into the intertemporal growth in trade since most of these proximity characteristics are not time varying. Gravity specification models, which are used to explain the level of trade, fail to capture changes in the growth of trade over time, especially of exports, and its association with the level of economic activity of the bilateral trading countries. Geographic proximity in theory often explains why neighboring countries disproportionately are engaged in exporting activities, as Krugman (1991) suggests that neighborhood export flows are so strong as to create natural trading blocs, but such explanations provide little insight into the sources of export growth, especially in the case of China.

\subsection{Trade Openness and Income}

China has now emerged as one of the world's largest exporting country as its exports grew 1769.59 percent between 1995 and 2015 (World Development Indicators (WDI), 2016). Also China has experienced an exceptional growth of its economy. Measured by GDP per capita, China has an outstanding increase of its per capita income from $\$ 308$ (constant 2010 US dollars) in 1978 to $\$ 6,108$ in 2015 (constant 2010 US dollars) (WDI 2016). Our prior knowledge, based upon economic growth theory, indicates that a "more open boarders" policy operates as an expansion factor of the domestic market taking advantage of economies of scale in an economy (Hummels \& Klenow, 2005; Frankel \& Romer, 1999; Dollar \& Kraay, 2002). Moreover, exports by fostering specialization and stimulating diffusion of new technologies and innovations results in improving the standard of living of people in exporting countries (Brückner \& Lederman, 2012; Frankel \& Romer, 1999; Dollar \& Kraay, 2002; and Rodriguez \& Rodrik, 2000). In the last 30 plus years, the contribution of exports to GDP in China increased by almost 21 percentage points (WDI, 2016) implying the significant contribution of exports to the country's output. This upward trend of China's exports of goods and services as a percent of GDP has become significant and it seems to have accelerated from 4.6 in 1978 to 19.2 in 1990 to 24.0 in 2015 (WDI, 2016).

Trade openness stimulates growth and efficiency by allowing producers in China to exploit areas in which they have a comparative advantage over foreign producers and by reducing real costs (Frankel \& Romer, 1999; Dollar $\&$ Kraay, 2002). A very large quantity of literature has actively discussed the role of trade, specifically exports, in fostering economic development. For instance, Frankel and Romer (1999) showed that differences in the value of bilateral trade across countries were positively correlated with the countries' levels of GDP per capita. Dollar 
and Kraay (2002) argue that both trade and institutions are important in the long run, but there is relatively larger role for trade and economic growth over shorter horizons. Brückner and Lederman (2012) provide evidence that bilateral trade causes growth for Sub-Saharan countries using different set of instruments. Thus, it is becoming imperative to understand and empirically evaluate China's surge in trade, especially exporting activities, and its steady growth progress.

\subsubsection{Identify Long-Term Growth of China's Exports}

It is crucial to apply methods that accurately quantify the long-term growth of China's exports. For this reason, following Tuan, Somwaru et al. (2016), we apply the Hodrick-Prescott (HP) (1997) method of Trend and Cycle Decomposition (TCD) for properly quantifying the growth of China's exports from 1979 through 2015 (see more detailed discussion in the Appendix of Tuan et al., 2016). We focus on this flexible statistical approach which we apply to various sectors of China's actual export data to capture the long-term dynamics of export growth. The major challenge in studying export growth and its fluctuations is to capture the long-term growth and to isolate the deviations from the stochastic growth path (Tuan et al., 2016). Using the HP/TCD method we are able to eliminate the deviations from the growth conduit of the actual data.

\subsection{Income and Export Growth Dynamics}

China's manufacturing exports continue to grow, from $47.7 \%$ of total merchandise exports in 1984 to an astonishing 93.9\% in 2015 (World Bank, 2016). Several studies suggest that manufacturing exports are associated with economic growth (Keller, 2001; Coe, Helpman, \& Hoffmaister, 1995). The annual growth rate in China's real gross domestic product (GDP) averaged above 10.0 percent per annum from 1990 to 2015, World Development Indicators (WDI) (World Bank, 2016).

These treads underlie the fact that international trade, specifically export activities, is beneficiary for a country's economic development (Aizenman \& Sushko, 2001). Thus, testing the correlation between income and growth of exports is essential and assessing the causative relationship between income and export growth patterns is critical. We use temporal data that allow us to perform statistical tests of causal direction. By using vector time series data instead of cross-sectional we can assert the degree of confidence in the direction and nature of causality than using only cross-sectional data.

\subsubsection{Non-Parametric Test: Income and Export Growth Dynamics}

The advantage of non-parametric methods over econometric methods is that nonparametric methods do not require specification of a functional form (Conover, 1980; Daniel, 1978) and account for more complicated nonlinear relationships between income and the growth of trade flow categories (Hollander \& Wolfe, 1973; Chiappori \& Salanie, 2000). Moreover, nonparametric techniques are used because income and growth of exports are related monotonically, and the exact sampling distribution can be obtained without requiring knowledge of their joint probability distribution. For this reason, we employ the Kruskal-Wallis test statistic, which is given by:

$$
H=\frac{12}{N(N+1)} \sum_{i=1}^{k} \frac{T_{i}^{2}}{n_{i}}-3(N+1)
$$

where $N$ is the sample size, $T_{i}$ is the sum of ranks for the $i^{\text {th }}$ group, and $n_{i}$ is the number of observation in the $i^{\text {th }}$ group. The test statistic $H$ approximately follows a chi-squared distribution with $k$ - 1 degrees of freedom, where $k$ is the number of groups or populations. Two data samples are independent if they come from distinct populations and the samples do not affect each other. The nonparametric test is performed to test whether the income and growth of export flows are independent. Rejection of the null hypothesis implies that export growth of China's trade has an effect on the country's income.

\subsubsection{Dynamic Properties of Exports and Income Growth: The Unit Root Test}

Given the dynamic properties of the variables that measure exports and economic growth it is important to test for stationarity of the data series as non-stationary variables can give misleading parameter estimates. The presence of unit roots indicates a non-stationary process that can lead to false inferences in time series analysis. In this respect we conduct unit root tests to access whether or not the series are stationary (Sargan \& Bhargava, 1983). If the data series follows stationary processes then we use the level values of the variables. However, if the variables are non-stationary, then the test is performed using first (or higher) differences. The Augmented Dickey-Fuller test (ADF) follows the general structure:

$$
\Delta y_{t}=\alpha+\beta_{t}+\gamma y_{t-1}+\delta_{1} \Delta y_{t-1}+\cdots+\delta_{p-1} \Delta y_{t-p+1}+\epsilon_{t}
$$

where $\Delta$ is the first difference operator, $\alpha$ is a constant, $\beta$ the coefficient of time trend, $p$ is the lag order of autoregressive process. The unit root test is then carried out under the null hypothesis $\gamma=0$ against the 
alternative hypothesis of $\gamma<0$. Once a value for the test statistic

$$
D F_{t}=\frac{\widehat{\gamma}}{S E(\widehat{\gamma})}
$$

is computed then it can be compared to the relevant critical value for the Dickey-Fuller (DF) test. If the test statistic is less than the critical value, then the null hypothesis of $\gamma=0$ is rejected and no unit root is present.

\subsection{Quantifying Export and Economic Growth}

This study aims to quantify the relationship between growth of China's exports and economic activity measured by per capita income and to make inference of trade growth on economic development. For this reason, we conduct causal analysis using multivariate data to identify the export growth and income relationship when external conditions change, such as government policies. We also apply formal econometric analysis to evaluate the potential impact of the trade growth, especially export growth, on income.

\subsubsection{Quantifying Export and Economic Growth: Causality}

Unlike standard statistics that are used to infer associations of variables, we employ causal analysis to help identify relationships between export growth and income. We use Granger causality (GC) approach to explore directed influences between China's exports to GDP per capita (GDPPC, thereafter) and vise-a-versa. The GC method does not rely on a priori specification of a model but by applying the concept of Granger causality it can determine the existence and direction of influence from export growth to GDPPC growth. Temporal data in a bivariate time-series context are used to test for causation and to identify the sources of directed influence between exports growth and output. Granger causality in the case of export growth rates and GDPPC can be stated as follows: export growth rates are said to Granger-cause GDPPC if GDPPC can be better predicted using both export growth rates and GDPPC than it can by using GDPPC alone. In particular, we test for the absence of Granger causality by estimating the following vector autoregressive (VAR) model:

$$
\begin{aligned}
& Y_{t}=a_{0}+a_{1} Y_{t-1}+\cdots+a_{p} Y_{t-p}+b_{1} X_{i, t-1}+\cdots+b_{p} X_{i, t-p}+\epsilon_{i, t} \\
& X_{i, t}=a_{0}+c_{1} X_{i, t-1}+\cdots+c_{p} X_{i, t-p}+d_{1} Y_{t-1}+\cdots+d_{p} Y_{t-p}+v_{i, t}
\end{aligned}
$$

and then testing the null hypothesis or $H_{0}=b_{1}=b_{2}=\cdots=b_{p}=0$, against $H_{a}:{ }^{\prime}$ not $=H_{0}^{\prime}$, is a test that $\mathrm{X}$ (in this case growth rates of exports of each aggregate commodity $i$ ) does not Granger-cause Y (in this case GDP per capita). Similarly, testing the null or $H_{0}=d_{1}=d_{2}=\cdots=d_{p}=0$, against $H_{a}:^{\prime}$ not $=H_{0}^{\prime}$, is a test that $\mathrm{Y}$ (in this case GDP per capita) does not Granger-cause $X$ (in this case growth rates of exports of each commodity). A rejection of the null implies there is Granger causality. Note that we use the "levels" of the data or the data have not been differenced.

We also applied the Toda and Yamamoto (1995) method to identify the direction(s) of causality between GDP per capita (GDPPC) and China's export growth of the six aggregate U.N. Broad Economic Categories (BEC, UN, 2011) BEC commodity categories. These tests call for special attention if the test statistics are to have standard asymptotic distributions. After determining the lags in the VAR equations we follow Toda and Yamamoto (1995) and then add extra lags of the variables equal in number to the maximum suspected order of integration to obtain the standard asymptotic distribution properties. We estimate the system and apply the usual Wald test to assess if the coefficients of the lagged export growth of the aggregate BEC commodities are jointly zero in the GDPPC equation. Similarly, we test if the coefficients of the lagged GDPPC variables are jointly zero in the export growth equations. In each case, the Wald test statistic follows asymptotically Chi Square distribution. The degrees of freedom equal to the number of "zero restrictions," even though GDPPC and the export growth of each of the BEC commodity groups are not exclusively stationary.

\subsubsection{Quantifying Export and Economic Growth: Seemingly Unrelated Regression (SUR)}

Finally, we develop a formal econometric model that is used to control for factors that associate income and growth rates of exports. The econometric model specified in a general form is as follows:

$$
y=f(g E x),
$$

where per capita income is a function of exporting activities, or specifically

$$
Y / N=\alpha+\gamma g E x_{i}+\vartheta P+\varepsilon_{i}
$$

where $(Y / N)$ stands for GDP divided by the active population, $g E x_{i}$ is long-term growth of China's exports of each aggregate commodity $i$, while $\gamma$ and $\vartheta$ are coefficients to be estimated and $P$ is a dummy that indicates adoption of policies, such as trade liberalization and acceleration of China's international processing activities through Foreign Invested Enterprises (FIEs) and Economic and Technological Development Zones (ETDZs). The variation of income not captured by our variables is thus summarized in $\varepsilon_{i}$ or the error term. International 
trade can be beneficial for a country's economic development as long as it translates into greater factor accumulation or productivity increases. In the above formulation we attempt to capture China's export-economic growth link. Exporting activity is considered a direct mechanism of spillovers from one country to another. Simply, absorption of exports from given country fosters the expansion of its exporting industries to other trading countries. Another direct mechanism of spillovers is through the technology embodied in the goods (both in physical and human capital) that are exchanged between countries. Through the trade channel, specifically exporting activities may contain intermediate goods and technologies that unavailable to the recipient country. The greater the quantity of these exports the greater will potentially be the spillovers from trade. Exporters might also receive feedback from importing nations (Blundell, Griffith, \& Reenen, 1995). However, in this study we focus on China's exporting activities. In light of the presence of these spillover channels, we attempt to quantify the relations of long-term growth of China's exporting activities on income measured as GDP per capita of the country's active population.

\section{Results}

This section describes the data employed and the analyses performed for exploring the dynamics of China's export growth, specifically export growth and income. We extensively present the export growth of China over time and country or country groups for better understanding of the trajectory of export growth.

\subsection{An In-depth Look on the Time-Series Datasets}

China's trade data at 4-digit Standardized International Trade Classification (SITC) Revision 4 (UN, 2016, Rev. 4) (UN, International Trade Statistics, 2016) level are used for trade pattern analyses. The data source is the United Nations Commodity Trade Statistics Database (UNCOMTRADE) maintained by the Statistics Division of United Nations (UN, 2016). China did not share public trade statistics with international organizations until 1984 and even then, the validity of some reported trade flows remained questionable and the trade statistical reporting systems were changed (from SITC to Harmonized System) over our study time period. Thus, we utilize China's reporting partners' data compiled by the UN. We adopted the same approach for processing and balancing the bilateral data as in Gehlhar (Gehlhar 1996 and 2012). We focus on the export growth rates of commodities as defined by the U.N. Broad Economic Categories (BEC) (UN 2011). Specifically, the SITC 4-digit data of commodities were aggregated using Statistical Analysis System (SAS) package to commodities codes defined by the U.N. BEC groups defined by the UN Statistics Division are as follows: capital goods, consumer durable goods, consumer non-durable goods, intermediate goods, primary energy goods, and primary non-energy goods (Tuan et al., 2016 and Appendix A). Unlikely in Tuan et al. (2016), this paper extends the dataset period through 2016.

The original classification by BEC was produced in 1961 by the United Nations Statistics Division for the summarization of data on international trade by large economic classes to provide a means for international trade statistics to be analyzed by the end-use. But it was also designed to serve as a means of converting external trade data compiled on SITC into end-use categories that are meaningful within the framework of the System of National Accounts (SNA). The SNA is the latest version of the international statistical standard for the national accounts, adopted by the United Nations Statistical Commission (UNSC) (UN, Department of Economics and Social Affairs, 2016). The subcategories of BEC can be aggregated to approximate SNA classes of goods, thus allowing external trade statistics to be considered jointly with other sets of general economic statistics, such as national accounts and industrial statistics, for national, regional or world-level economic analysis. Table 1 presents descriptive statistics of the growth rates of China's exports of the various BEC categories and the country's GDPPC.

\subsubsection{Growth Dynamics-- Country/Country}

Appendix Table A1 shows China's trade growth patterns with selective developed and developing countries/regions. In the 1990's the high-income country group was among the leading growth destinations of China's total merchandise exports. This trade dependency with China indicates that changes in China's trade openness policies generated relatively large impact on its importing partners. In the 2000s the growth patterns of China's exports show a significant departure from the previous decades. (Appendix Table A1). During the entire period under study developed countries were China's major export growth destination. This is consistent with the prediction of macroeconomic-based trade models and reinforces the importance of economic conditions such as currency depreciation or appreciation on trade and its growth. In the 2000s however developing countries seem to account for most of China's imports of all products as the growth rate follows an upward trend surpassing other countries/country groups (Appendix Table A1). Developing country group imports' growth exceeds its exports' growth. In the 2000s (2001-2015), China's import growth rates exceeded its export growth rates 
indicating China's growing dependence on goods from foreign suppliers. China's exports to and imports from South East Asian countries, South America countries, and Africa Countries follow the same growth pattern especially in the last two decades (Appendix table A1).

Table 1. Statistics of China's export growth by aggregate commodity and GDP per capita

\begin{tabular}{|c|c|c|c|c|c|c|}
\hline Item & Minimum & 1st Quantile & Median & Mean & 3rd Quantile & Maximum \\
\hline Export growth of capital goods & 16.33 & 40.91 & 45.60 & 42.63 & 47.77 & 58.71 \\
\hline Export growth of consumer non-durables & & 13.28 & 22.95 & 22.49 & 32.12 & 34.19 \\
\hline Export growth of consumer durables & 16.40 & 19.63 & 25.19 & 24.85 & 29.16 & 34.22 \\
\hline Export growth of intermediate goods & 12.76 & 14.87 & 16.97 & 18.52 & 20.45 & 28.64 \\
\hline Export growth of primary non-energy & 0.89 & 3.65 & 8.52 & 7.72 & 11.91 & 13.54 \\
\hline Export growth of primary energy goods & -3.51 & -2.38 & 2.72 & 4.54 & 8.31 & 24.73 \\
\hline GDPPC (GDP per capita) & 50.09 & 89.41 & 159.65 & 204.63 & 281.78 & 571.22 \\
\hline
\end{tabular}

* Growth rates - annual, 1979 through 2015.

Source: Authors' calculations.

\subsubsection{Growth Dynamics-Commodities}

Capital goods amounting to almost two-thirds of China's total imports display China's comparative advantage in production 'by stage'. China's processing trade pattern in terms of growth rates is characterized by strong import growth of intermediate goods while in the later years China's import growth of primary goods, such as raw grains, soybeans, iron ore, and other minerals is outstanding. Regarding primary energy goods China's import and export growth rates declined significantly in the recent years given the higher petroleum and coal prices. These findings tend to weaken the Krugman-Bhagwati (Bhagwati, 1992) debate that neighborhood determines the direction of trade as geographic proximity is irrelevant in the case of China's export and import growth.

In the 1990s and 2000s China's export and import growth of capital goods, consumer durable and non-durable is dominated by the increased demand from high income developing countries, like India, due to increase incomes.

\subsection{Non-Parametric Testing: Income and Export Growth Dynamics}

Table 2 presents the test results of the non-parametric test of income, measured by GDP per capita, and export growth of commodity categories as we attempt to capture China's export-economic growth nexus. Two data samples are independent if they come from distinct populations and the samples do not affect each other. The nonparametric test is performed to test whether the income and growth of export flows are independent. Rejection of the null hypothesis implies that export growth of China's trade has an impact on the country's income. The Kruskal-Wallis $\mathrm{X}^{2}$ statistic rejects the null hypothesis at $1 \%$ significant level implying that income measured by GDP per capita affected by export growth. These results show an ex post mode evidence that export growth affected China's economic growth measured by income during the period under study. The Spearman correlation, $\rho$, assessing monotonically the relationship (whether linear or not) between export growth and GDP per capita (Daniel, 1990) indicates a strong positive correlation with all BEC categories except the primary energy group (Table 2).

Table 2. Testing for the independence of GDP per capita and export growth of China's aggregate commodities

\begin{tabular}{|c|c|c|c|c|}
\hline Item & Kruskal-Wallis & P-values & $\begin{array}{l}\text { Spearman } \\
\text { correlation }\end{array}$ & P-values \\
\hline GDP per capita and export growth of capital goods & 29.013 & 0.465 & 4.9443 & $<0.0001$ \\
\hline GDP per capita and export growth of consumer non-durables & 28.994 & 0.413 & 5.2935 & $<0.0001$ \\
\hline GDP per capita and export growth of consumer durables & 30.039 & 0.477 & 4.4795 & $<0.0001$ \\
\hline GDP per capita and export growth of intermediate goods & 29.653 & 0.438 & 4.9155 & $<0.0001$ \\
\hline GDP per capita and export growth of primary non-energy & 28.985 & 0.463 & 0.7895 & 0.4328 \\
\hline GDP per capita and export grwoth of primary energy goods & 29.946 & 0.478 & -0.1042 & 0.9207 \\
\hline Asymptotic statistics & $33.21\left(\mathrm{X}^{2}\right)$ & & & \\
\hline
\end{tabular}

Source: Authors' caluclations. 


\subsection{Testing for the Dynamic Properties of Exports and Income Growth: The Unit Root Test}

The Dickey-Fuller test indicates that for most of the export growth series we reject the null hypothesis of the unit root presence (Table 3). The Augmented Dickey-Fuller (ADF) test (Dickey \& Fuller, 1979), the Phillips-Perron (PP) test (Phillips \& Perron, 1988) and the Kwiatkowski, Phillips, Schmidt, and Shin (KPSS) test (Kwiatkowski et al., 1992) fail to reject the null hypothesis of the unit root (Table 3).

Table 3. Unit root and stationarity test results

\begin{tabular}{|c|c|c|c|c|c|c|c|}
\hline Variable & $\begin{array}{r}\text { ADF test statistic } \\
\text { (Ho: unit root) }\end{array}$ & $\begin{array}{r}\mathrm{ADF} \\
\mathrm{P} \text {-value }\end{array}$ & $\begin{array}{r}\text { PP test statistic } \\
\text { (Ho: unit root) }\end{array}$ & $\begin{array}{r}P P \\
\text { P-value }\end{array}$ & $\begin{array}{l}\text { KPSS test statistic } \\
\text { (Ho: stationarity) }\end{array}$ & $\begin{array}{l}\text { KPSS } \\
\text { P-value }\end{array}$ & $\begin{array}{c}\text { Order of } \\
\text { Integration }\end{array}$ \\
\hline Export growth of capital goods & -2.92 & 0.22 & -6.67 & 0.70 & 1.18 & $0.01 * * *$ & $\mathrm{I}(1) \operatorname{orI}(0)$ \\
\hline Export growth of consumer non-durables & -2.05 & 0.55 & $-8.75^{*}$ & 0.04 & 1.55 & $0.01 * * *$ & $\mathrm{I}(1) \operatorname{orI}(0)$ \\
\hline Export growth of consumer durables & $-3.21 *$ & 0.11 & -9.61 & 0.51 & 1.11 & $0.01 * * *$ & $\mathrm{I}(1) \operatorname{orI}(0)$ \\
\hline Export growth of intermediate goods & -0.85 & 0.94 & -4.58 & 0.84 & 1.29 & $0.01 * * *$ & $\mathrm{I}(1) \operatorname{orI}(0)$ \\
\hline Export growth of primary non-energy & $-3.35^{*}$ & 0.08 & -1.78 & 0.97 & 0.41 & $0.07 * *$ & $\mathrm{I}(1) \operatorname{orI}(0)$ \\
\hline Export growth of primary energy goods & -2.81 & 0.26 & -3.17 & 0.92 & 0.39 & $0.08 * *$ & $\mathrm{I}(1) \operatorname{orI}(0)$ \\
\hline GDPPC (GDP per capita) & 1.36 & 0.99 & 3.93 & 0.99 & 1.44 & 0.01 & $\mathrm{I}(1) \operatorname{orI}(0)$ \\
\hline
\end{tabular}

* Growth rates - annual, 1979 through 2015.

Ho: Null Hypothesis.

Asterics *, **, and *** denote acceptance of the null hypothesis at the $10 \%, 5 \%$, and $1 \%$ significance level, respectively.

An I $(0)$ series is a stationary series.

An I(1) contains one unit root.

Source: Authors' calculations.

Thus, the dynamic properties of the variables employed to measuring exports and economic growth are stationarity as we reject the presence of unit roots. The presence of unit roots indicates a non-stationary process that can lead to false inferences in time series analysis. In this respect after conducting the unit root tests we use the level values of the variables involved.

\subsection{Causality - Export Growth and Income}

Table 4 presents the diagnostic tests on causality. The tests suggest that there is strong evidence of causality from the export growth of capital goods and consumer non-durable goods to GDPPC. We clearly fail to reject non-causality in this direction. There is also evidence that the causality is bi-directional for consumer durable goods, intermediate goods, and primary non-energy goods and GDPPC. There is absence of causality from consumer energy goods to GDPPC but causality from GDPC to consumer energy goods (see Table 4).

Table 4. Causality tests

\begin{tabular}{|c|c|c|c|c|}
\hline \multirow[b]{2}{*}{ Equation } & \multicolumn{4}{|c|}{ Ward $^{1}$} \\
\hline & $\mathrm{X}^{2}$ & $\mathrm{P}$-value & $\mathrm{F}$ & $\mathrm{P}$-value \\
\hline Export growth of capital goods & 116.5 & $<0.0001^{* * *}$ & 19.4 & $0.0011^{* * *}$ \\
\hline GDPPC (GDP per capita) & 15.7 & $0.016^{* * *}$ & 2.6 & 0.13 \\
\hline Export growth of consumer non-durables & 108.0 & $<0.0001 * * *$ & 18.0 & $0.0013^{* * *}$ \\
\hline GDPPC (GDP per capita) & 7.6 & 0.27 & 1.3 & 0.39 \\
\hline Export growth of consumer durables & 59.0 & $<0.0001^{* * *}$ & 9.8 & $0.0068 * * *$ \\
\hline GDPPC (GDP per capita) & 26.6 & $0.00017^{* * * *}$ & 4.4 & $0.046^{* *}$ \\
\hline Export growth of intermediate goods & 13.3 & $<0.0001^{* * *}$ & 2.2 & $0.038^{* *}$ \\
\hline GDPPC (GDP per capita) & 277.9 & $<0.0001^{* * *}$ & 46.3 & $<0.0001^{* * *}$ \\
\hline Export growth primary non-energy & 349.9 & $<0.0001^{* * *}$ & 58.3 & $<0.0001^{* * *}$ \\
\hline GDPPC (GDP per capita) & 552.5 & $<0.0001^{* * *}$ & 92.1 & $<0.0001^{* * *}$ \\
\hline Export growth of primary energy goods & 14.9 & 0.021 & 2.5 & 0.15 \\
\hline GDPPC (GDP per capita) & 40.9 & $<0.0001^{* * *}$ & 6.8 & $0.017^{* *}$ \\
\hline
\end{tabular}

${ }^{1}$ The Wald causality test statistic is asymptotically $\mathrm{X}^{2}$

$* 10 \%, * * 5 \%$, and $* * * 1 \%$ significance level

Source: Authors' calculations. 


\subsection{Export Growth, Income and Policy Analysis}

Applying seemingly unrelated regression (SUR) we assess the impact of the export growth on income (Tables 5 and 6). The dependent variable in our regressions is income per capita (Table 5) as well as income per capita in logs (Table 6). The exogenous variables include the export growth of China's broad economic categories of goods (Table 5) and the log of these variables (Table 6).

Table 5. SUR on income and export growth

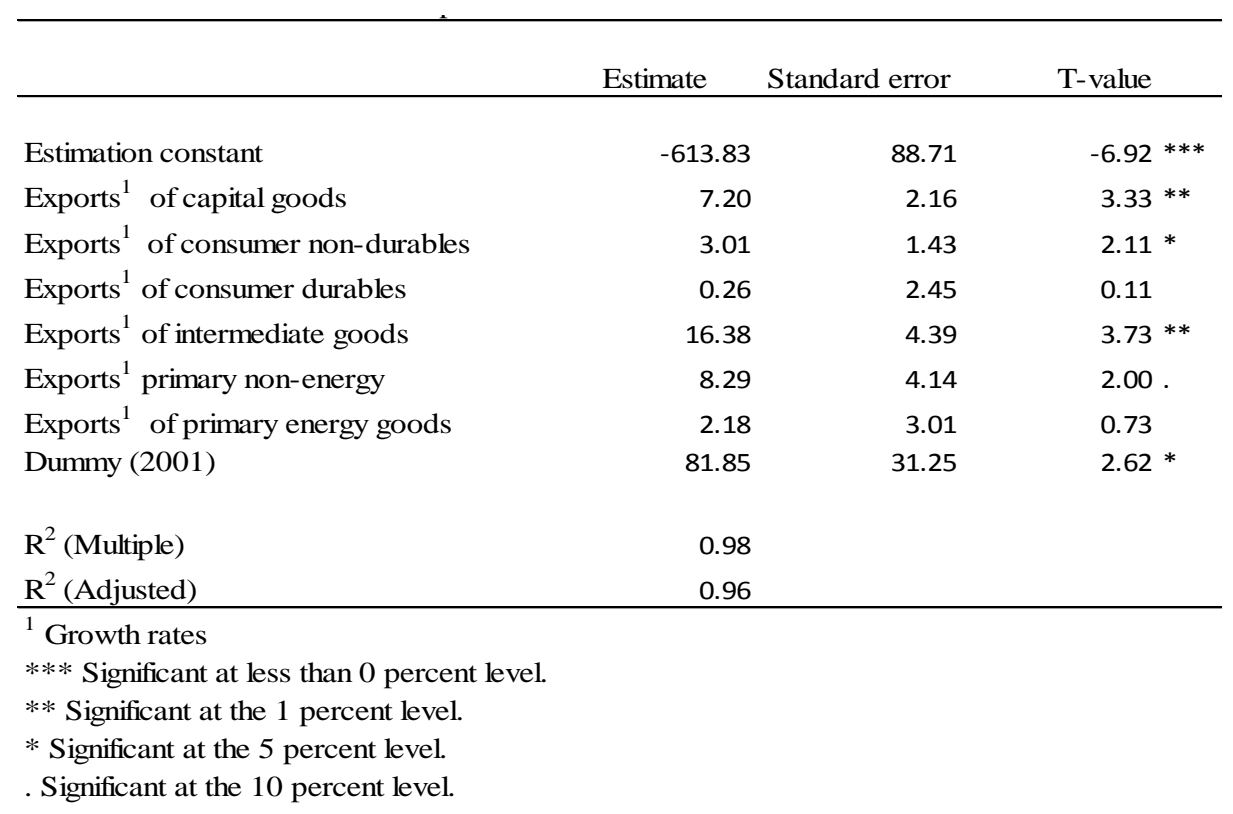

There are many other variables that affect income, but in this study, we focus on how export growth impacts income. The regression results show a positive and statistical significant relationship between income and export growth of capital goods, consumer non-durable goods, intermediate goods, and primary non-energy goods. Export growth of consumer durable goods, and export growth of goods of primary energy have a positive but statistical insignificant relationship with the income. Many studies suggest that economic growth (measured by income) of developing countries is positively related with the exports of manufacturing products (Grossman \& Helpman, 1989; and Hausmann, Hwang, \& Rodrik, 2005).

In the double log specification (Table 6) all estimates still have a positive impact on income with exception of the growth of export of primary energy goods. Furthermore, all coefficients with exception of export growth of capital goods are statistical insignificant. The largest positive impact on income is that of the export growth of the intermediate goods. In this case, a one percentage point of export growth of intermediates is associated with an increase of 1.68 percent of income per person. The dummy variable, which equals 1 beginning with 2001 and 0 otherwise, captures China's accession to WTO and adoption of trade policies that granted preferential tariff treatment to assembling and processing activities as well as Foreign Direct Investment (FDI), is positive and statistical significant (Table 5) but insignificant in the log specification (Table 6). China because of its accession to WTO has adopted open trade policies, through tariff exemption, which have favored assembly and processing operations. This in turn, has accelerated China's international processing activities resulting in high export growth of manufacturing products. In other words, trade openness has stimulated growth and efficiency by allowing producers in China to exploit areas in which they have a comparative advantage. The statistical significance of the trade policy is in agreement with our prior knowledge, which is based upon economic growth theory that is growth follows its secular trend along trade expansion. 
Table 6. SUR and log income and export growth

\begin{tabular}{|c|c|c|c|}
\hline & Estimate & Standard error & T-value \\
\hline Estimation constant & -5.68 & 0.51 & $-11.22 * * *$ \\
\hline $\log$ Exports $^{1}$ of capital goods & 0.72 & 0.16 & $4.54 * *$ \\
\hline $\log$ Exports ${ }^{1}$ of consumer non-durables & 0.20 & 0.74 & 0.27 \\
\hline $\log$ Exports ${ }^{1}$ of consumer durables & 0.47 & 0.34 & 1.38 \\
\hline $\log$ Exports $^{1}$ of intermediate goods & 1.68 & 1.12 & 1.50 \\
\hline $\log$ Exports $^{1}$ primary non-energy & -0.52 & 1.05 & -0.50 \\
\hline $\log$ Exports ${ }^{1}$ of primary energy goods & 0.01 & 0.08 & 0.12 \\
\hline Dummy (2001) & 0.09 & 0.05 & 1.76 \\
\hline $\mathrm{R}^{2}$ (Multiple) & 0.99 & & \\
\hline $\mathrm{R}^{2}$ (Adjusted) & 0.99 & & \\
\hline $\begin{array}{l}{ }^{1} \text { Growth rates } \\
* * * \text { Significant at less than } 0 \text { percent level. } \\
* * \text { Significant at the } 1 \text { percent level. } \\
* \text { Significant at the } 5 \text { percent level. } \\
\text {. Significant at the } 10 \text { percent level. }\end{array}$ & & & \\
\hline
\end{tabular}

China's outstanding performance in trade growth is rooted to changes in its policies and more likely to the country's increased involvement in the international segmentation of production processes. China's strong specialization in the downstream segments of production or processing is associated with trade openness and is also linked with rapid diversification in consumer goods.

\section{Discussion}

In this study we attempt to empirically assess the dynamic features of China's trade flows and develop a comprehensive profile of China's trade growth patterns and their effect on China's economic growth measured by GDP per capita. Applying the HP approach, we are able to attain the long-term trend of China's trade flow growth and remove the cyclical fluctuations due to annual variability. Moreover, China's long-term trends of trade growth can better reveal the underlie China's trade growth patterns. We find that other developing countries not only are playing a complementary role in China's export growth during the period under study and that China's export growth clearly indicates that the adjacency-neighborhood partners alone is unlikely to explain its unprecedented growth in exports and imports.

This study finds that in the 1990's the high-income country group was among the leading growth destinations of China's total merchandise exports. Examining China's exports patterns over time enhances our understanding of China's production of final goods, especially consumer durable goods and its effect on China's economic growth.

The non-parametric test of income measured by GDP per capita (GDPPC) and trade growth of the U.N. Broad Economic Categories (BEC) are statistical significant indicating the dependence of income and export growth rates. These results show, ex post, evidence that export growth affects income during our study period. The correlation test of independence indicates a strong positive correlation between income and export growth with all broad economic commodity categories except the primary energy group. The causality tests suggest that there is strong evidence of causality from the export growth of capital goods and consumer non-durable goods to GDPPC or we fail to reject non-causality in this direction. There is also evidence that the causality is bi-directional for consumer durable goods, intermediate goods, and primary non-energy goods and GDPPC while there is absence of causality from consumer energy goods to GDPPC but causality from GDPC to consumer energy goods.

Our analysis based on ex-post long-term time series highlights China's growth rates of exports and its causal association with income measured by GDPPC. By decomposing China's overall trade by major categories, we gain deeper insight into causal relationships with income and the impact of its policies on trade. The regression results show a positive and statistical significant relationship between income and export trade growth of aggregate goods categories. This in agreement with the recent theory that assumes that imitation by developing countries of goods invented in developed countries is always positively related with economic growth measured by income. Furthermore, China's trade openness has stimulated growth and efficiency by allowing producers in 
China to exploit areas in which they have a comparative advantage. The statistical significance of the trade policy is in agreement with our prior knowledge, which is based upon economic growth theory that is growth follows its secular trend along trade expansion.

\section{Disclaimer}

The views expressed herein are those of the authors and not necessarily those of the U.S. Department of Agriculture.

\section{References}

Aizenman, J., \& Sushko, V. (2001). Capital Flows Catalyst or Hindrance to Economic Take-Offs? NBER Working paper, No 5712, 2001.

Backus, D. K., \& Kehoe, P. J. (1992). International Evidence on the Historical Properties of Business Cycles. American Economic Review, 82(4), 864-888.

Baier, S. L., \& Bergstrand, H. (2001). The growth of world trade: Tariffs, transport costs, and income similarity. Journal of International Economics, 53, 1-27. https://doi.org/10.1016/S0022-1996(00)00060-X

Baxter, M., \& Robert, K. (1999). Measuring Business Cycles: Approximate Band-Pass Filters for Economic Time Series. The Review of Economics and Statistics, 81(4), 573-593. https://doi.org/10.1162/003465399558454

Bhagwati, J. (1992). Regionalism vs. Multilateralism. The World Economy, 15(5). https://doi.org/10.1111/j.1467-9701.1992.tb00536.x

Blackburn, K., \& Ravn, M. O. (1992). Business Cycles in the U.K.: Facts and Fictions. Economica, 59, 383-401. https://doi.org/10.2307/2554886

Brückner, M., \& Lederman, D. (2012). Trade Causes Growth in Sub-Saharan Africa. World Bank Policy Research Working Paper No. 6007. https://doi.org/10.1596/1813-9450-6007

Burns, A., \& Mitchell, W. C. (1946). Measuring Business Cycles. New York, New York: National Bureau of Economic Research.

Coe, D. T., Helpman, E., \& Hoffmaister, A. W. (1995). North-South R\&D Spillovers. National Bureau of Economic Research, Working paper No 5048. https://doi.org/10.3386/w5048

Cooley, T., \& Prescott, E. C. (1995). Economic Growth and Business Cycles. In T. Cooley (Ed.), Frontiers of Business Cycle Research. Princeton: Princeton University Press.

Daniel, W. W. (1990). Spearman rank correlation coefficient. Applied Nonparametric Statistics (2nd ed., pp. 358-365). Boston: PWS-Kent.

Danthine, J., \& Donaldson, J. B. (1993). Methodological and Empirical Issues in Real Business Cycle Theory. European Economic Review, 37(1), 1-35. https://doi.org/10.1016/0014-2921(93)90068-L

Deardorff, A., \& Stern, R. (1994). Multilateral Trade Negotiations and Preferential Trade Arrangements. In Deardoff, \& Stern (Eds.), Analytical and Negotiating Issues in the Global Trading System. University of Michigan Press. https://doi.org/10.3998/mpub.13289

Dickey, D. A., \& Fuller, W. (1979). Distribution of the Estimators for Autoregressive Time Series with a Unit Root. Journal of the American Statistical Association, 74(366a), 427-431. https://doi.org/10.1080/01621459.1979.10482531

Dollar, D., \& Kraay, A. (2002). Institutions, Trade, and Growth. World Bank Policy Research Working Paper No. 3004.

Engel, C., \& Rogers, J. H. (1996). How Wide is the Border? American Economic Review, 86(5), 1112-1125.

Fiorito, R., \& Kollintzas, T. (1994). Stylized Facts of Business Cycles in the G7 from a Real Business Cycles Perspective. European Economic Review, 38(2), 235-269. https://doi.org/10.1016/0014-2921(94)90057-4

Frankel, J. A. (1996). Recent Exchange Rate Experience and Proposals for Reform. American Economic Review, $86(2)$.

Frankel, J. A. (1997). Regional Trading Blocs in the World Trading. Institute of International Economics, Washington, DC.

Frankel, J. A., \& Romer, D. (1999). Does Trade Cause Growth? American Economic Review, 89(3), 379-399. https://doi.org/10.1257/aer.89.3.379 
Frankel, J., Romer, D., \& Cyrus, T. (1996). Trade and Growth in East Asian Countries: Cause and Effect? National Bureau of Economic Research Working Paper, Cambridge, MA, No. 5732.

Gehlhar, M. (2012). Reconciling Bilateral Trade Data for Use in GTAP. Global Trade Analysis Project (GTAP) Technical Paper No.10. Retrieved from https://www.gtap.agecon.purdue.edu/databases/trade_data.asp

Grossman, G., \& Helpman, E. (1989). Product development and international trade. The Journal of Political Economy, 97(6), 1261-1283. https://doi.org/10.1086/261653

Gupta, D. D. (1989). China Engaged: Integration with the Global Economy. World Bank Publication.

Hausmann, R., Hwang, J., \& Rodrik, D. (2005). What you export matters. NBER Working paper 11905. National Bureau of Economic Research, Cambridge MA. https://doi.org/10.3386/w11905

Hodrick, R. J., \& Prescott, E. C. (1997). Postwar U.S. Business Cycles: An Empirical Investigation. Journal of Money, Credit and Banking, 29. https://doi.org/10.2307/2953682

Hollander, M., \& Wolfe, D. A. (1973). Nonparametric Statistical Methods (pp. 115-120). New York: John Wiley $\&$ Sons.

Hummels, D., \& Klenow, P. (2005). The Variety and Quality of a Nation's Exports. American Economic Review, 95, 704-723. https://doi.org/10.1257/0002828054201396

Keller, W. (2001). The Geography and Channels of Diffusion at the World's Technology Frontier. National Bureau of Economic Research Working paper No 8150. https://doi.org/10.3386/w8150

King, R., \& Rebelo, S. (2000). Resuscitating Real Business Cycles. National Bureau of Economic Research (NBER) Working Paper 7534. https://doi.org/10.3386/w7534

Krugman, P. (1991). Is Bilateral Bad? In E. Helpman, \& A. Razin (Eds), International Trade and Trade Policy, Cambridge, MA, MIT Press.

Kwiatkowski, D., Phillips, P. C. B., Schmidt, P., \& Shin, Y. (1992). Testing the Null Hypothesis of Stationarity against the Alternative of a Unit Root. Journal of Econometrics, 54, 159-178. https://doi.org/10.1016/0304-4076(92)90104-Y

Kydland, F., \& Prescott, E. C. (1982). Time to Build and Aggregate Fluctuations. Econometrica, 50(6), 1345-1370. https://doi.org/10.2307/1913386

Kydland, F., \& Prescott, E. C. (1990). Business Cycles: Real Facts and a Monetary Myth. Federal Reserve Bank of Minneapolis Quarterly Review, 14, 3-18.

Lucas, R. (1975). An Equilibrium Model of Business Cycle. The Journal of Political Economy, 83(6). https://doi.org/10.1086/260386

Markusen, J. R. (1986). Explaining the volume of trade. American Economic Review, 76, 1002-11.

Naughton, B. (1996). Growing Out of the Plan: Chinese Economic Reform, 1978-1993. Cambridge University Press.

Naughton, B. (1997). The China Circle: Economics and Technology in the PRC, Taiwan, and Hong Kong. Brookings Institute Press.

Naughton, B. (2004). China's Economic Growth and Technology Development: International Linkages and Implications for the U.S. Prepared Statement for a hearing before the U.S-China Economic and Security Review Commission, One Hundred Eighth Congress, Second Session.

Ng, F., \& Yeats, A. (1999). Production Sharing in East Asia: Who does What, for Whom and Why? World Bank, Policy Research Working Paper, WPS 2197.

Parsley, D., \& Wei, S. J. (1996). Convergence to the Law of One Price without Trade Barriers or Currency Fluctuations. Quarterly Journal of Economics, 111(4), 1211-1236. https://doi.org/10.2307/2946713

Phillips, P., \& Perron, P. (1988). Testing for a Unit Root in Time Series Regression. Biometrika, 75, 335-346. https://doi.org/10.1093/biomet/75.2.335

Ravn, M., \& Uhlig, H. (2002). On Adjusting The Hodrick-Prescott Filter For The Frequency of Observations, The Review of Economics and Statistics, 84(2), 371-380. https://doi.org/10.1162/003465302317411604

Rodriguez, F., \& Rodrik, D. (2000). Trade Policy and Economic Growth: A Skeptic's Guide to the Cross-National Evidence. In B. Bernanke, \& K. Rogoff (Eds.), NBER Macro Annual 2000. Cambridge, Massachusetts: National Bureau of Economic Research. 
Rose, A. K. (1991). Why has trade grown faster than income? Canadian Journal of Economics, XXIV(2), 417-27. https://doi.org/10.2307/135631

Sargan, J. D., \& Bhargava, A. (1983). Testing Residuals from Least Squares Regression for Being Generated by the Gaussian Random Walk. Econometrica, 51(1), 153-174. https://doi.org/10.2307/1912252

Spearman, C. (1904). The proof and measurement of association between two things. American Journal of Psychology, 15, 72-101. https://doi.org/10.2307/1412159

Statistical Analysis System (SAS). SAS Institute Inc., 100 SAS Campus Drive, Cary, NC 27513-2414, USA. Retrieved from http://www.sas.com

Stein, E., \&Frankel, J. (1994). The welfare implications of continental trading blocs in a model with transport costs. Pacific Basin Working Paper Series 94-03.

Stock, J. H., \& Watson, M. W. (1998). Business Cycle Fluctuations in U.S. Macroeconomic Time Series. NBER Working Paper 6528.

Subramanian, A., \& Martin, K. (2013). The Hyperglobalization of Trade and Its Future. Working Paper (WP 13 - 6), the Peterson Institute for International Economics, Washington, DC. https://doi.org/10.2139/ssrn.2297994

Toda, H. Y., \& Yamamoto, T. (1995). Statistical Inference In Vector Autoregressions With Possible Integrated Processes. Journal of Econometrics, 66, 225-250. https://doi.org/10.1016/0304-4076(94)01616-8

Tuan, F., Somwaru, A., Wang, S. L., \& Tsakiridou, E. (2016). The Dynamics of China's Export Growth: An Intertemporal Analysis. South-Eastern Europe Journal of Economics, 1, 7-27.

United Nations. (2002). Department of Economic and Social Affairs, Statistics Division, Trade Statistics Branch, ESA/STAT/AC.234/25.

United Nations. (2011). Department of Economic and Social Affairs, Statistics Division, Trade Statistics Branch, ESA/STAT/AC.234/25. Retrieved from http://unstats.un.org/unsd/iiss/Classification-by-Broad-Economic-Categories-BEC.ashx

United Nations. (2015). Commodity Trade Statistics Database (UNCOMTRADE), Statistics Division. Retrieved from http://comtrade.un.org/db/

United Nations. (2015). Department of Economics and Social Affairs, Statistics Division, System of National Accounts 2008 - 2008 SNA. Retrieved from http://unstats.un.org/unsd/nationalaccount/sna2008.asp

United Nations. (2015). International Trade Statistics, Commodity Trade Statistics, Statistics Division. Retrieved from http://unstats.un.org/unsd/tradekb/Knowledgebase/Harmonized-Commodity-Description-and-Coding-Syste ms-HS

United Nations. (2015). Statistics Division, Methods and Classifications, Standard International Trade Classification Codes, Rev. 4. Retrieved from http://unstats.un.org/unsd/cr/registry/regcst.asp?Cl=28

World Development Indicators (WDI). (2014). International Bank for Reconstruction and Development (IBRD), World Databank, Database. Retrieved from http://databank.worldbank.org/data/views/variableSelection/selectvariables.aspx?source=world-developmen t-indicators\#c_c

\section{Appendix 1}

\section{Developing the Measures of Trade and Export Growth}

Because this study quantifies the relationship between growth of China's trade flows and economic activities measured by per capita income and makes inference of trade growth and income nexus we considered that it is crucial to apply methods that accurately determine the long-term growth of China's trade flows.

The time series data of trade from and to China are used to better understand the changes and trends in China's trade flows along with the country's economic growth and policy implementations. An examination of the time path of trade flows for any economy swiftly reveals that both exports and imports tend to fluctuate about a long-term growth path. These fluctuations are irregularly spaced and of varying amplitude and duration. On the other hand, China's output quickly indicates that the output and other economic aggregates and their components tend to follow a prolonged long-term growth path along with fluctuations or so-called "growth cycles" (Lucas, 
1975; Cooley \& Prescott, 1995; and Burns \& Mitchell, 1946). A challenging issue in studying growth and its fluctuations is to establish co-movements and timing characteristics of economic indicators.

Research on growth faces the problem of how to capture the features of the long-term growth and isolate the deviations from the growth path. Most of the recent literature work uses a technique that accounts for the growth and the deviations from the growth. The technique is known as the Hodrick-Prescott (HP) (1997) method or Trend and Cycle Decomposition (TCD). We apply the HP/TCD method and derive the growth rates of China's exports and imports. The section below provides a quick overview of the method used (see also Tuan, Somwaru et al., 2016)

\section{Method: HP or Trend and Cycle Decomposition}

The HP/TCD approach is the standard technique in macroeconomics for separating the long run trend in a data series from short run fluctuations, for example, Backus and Kehoe (1992), Blackburn and Ravn (1992), Danthine and Donaldson (1993), Fiorito and Kollintzas (1994), Kydland and Prescott (1990). It has also been applied in studies in which artificial data from a model are compared with the actual data (Backus, Kehoe, \& Kydland, 1992; Cooley \& Hansen, 1989; Hansen, 1985; and Kydland \& Prescott, 1982; King \& Rebelo, 2000; Baxter \& King, 1999). While different types of criticism can be found in the literature on the HP method, Ravn and Uhlig (2002) state and we quote "the HP-filter has withstood the test of time and the fire of discussion remarkably well."

We apply the HP/TCD method to obtain the trajectory of China's exports. For details on the method see Tuan et al. (2016). Unlikely in Tuan, Somwaru study we extend the data series through 2015 (Tuan et al., 2016).

By applying the HP/TCD approach and capturing the annualized growth rates, we obtain factually based data series of the dynamic features of China's trade flows. The trade flow data exhibit relatively large annual variability due to a variety of reasons. Many of the causes for these fluctuations in year to year data are not essential for capturing the "true" trajectory in China's trade flow growth. Instead, these deviations tend to obscure the underlying long-term trend in trade growth rates. China's long-term trends of growth in trade can better revealed the underlie China's trade growth patterns using the HP/TCD.

\section{Appendix 2}

\section{Commodity Categories}

This section presents the BEC categories of the broadly defined commodities. Under each category the major products and commodities codes are listed. For example, commodities that have been classified by BEC as "primary" or category 1 are products of primary sectors of the economy, i.e., farming, forestry, fishing, hunting and the extractive industries. In addition, commodities which are products of other sectors, such as manufacturing, are also classified as primary if nearly all the value of the product is contributed by one of the primary sectors of the economy, i.e. cotton undergoes physical transformation when ginned but almost all the value of ginned cotton derives from the agricultural sector. Canned and prepared foods, on the other hand, are products of the food-processing industry; they are therefore excluded from the primary category in BEC and are classified as processed. A commodity is classified as primary if it is a product of farm, forest, fishing and hunting or an extractive industry to whose value transformation has made only a minor contribution. Note that waste and scrap materials are also classified as primary commodities in BEC. If a commodity is not defined as primary it is classified as processed in BEC (United Nations, 2011, 2015, 2002, 2015, 2015, 2015). Overall, the purpose of the classification is to analyze international trade statistics by large economic classes of commodities, distinguishing food, industrial supplies, capital equipment, consumer durables and consumer non-durables in order to supplement the summary data already compiled on the basis of the sections of the Standard International Trade Classification (SITC).

Besides trade flows with each individual country in the dataset, we created country groups, such as: EU-25, High Income, Developing, Ocean, High Income South East Asian, South and South East Asian, Central and South American, High Income Oil Exporting, African, and Transitional Economies (Appendix: Country and Country Groups, below). Some country groups like African or Transitional Economies are subsets of larger groups such as Developing country group (Appendix: Country and Country Groups, below).

Since EU-25 was established in May 2004, we started with EU-12 and we added countries as the EU enlargement progresses over time. For example, in January 1995 Austria, Finland and Sweden joined the EU-12 to form EU-15. Prior to 1995 we account for the bilateral trade of these three countries with China in the High-Income country group. In May 2004 ten countries joined the EU-15 that is, Cyprus, Czech Republic, 
Estonia, Hungary, Latvia, Lithuania, Malta, Poland, Slovakia, and Slovenia, to form the EU-25. Prior to 2004 we account for the bilateral trade of these ten countries with China in the Developing country group. National income data from the World Bank's World Development Indicator are also used to obtain the overall picture of China's growth, trade, and economy. Our trade data are in nominal terms while our analyses focus mainly on shares and growth rates.

Appendix Table A1. China's estimates of total merchandise trade annual growth* by trading partners

\begin{tabular}{|c|c|c|c|}
\hline Item & $1980 s$ & $\begin{array}{c}1990 s \\
\text { average }\end{array}$ & $2000 s$ \\
\hline Total imports & 17.36 & 13.39 & 24.08 \\
\hline Total exports & 16.67 & 16.75 & 22.25 \\
\hline Imports from Developed countries & 14.57 & 13.56 & 18.68 \\
\hline Exports to Developed countries & 14.30 & 19.73 & 23.53 \\
\hline Imports from Developing countries & 20.27 & 13.31 & 27.93 \\
\hline Exports to Developing countries & 18.05 & 15.03 & 21.15 \\
\hline Imports from the USA & 16.94 & 13.28 & 17.95 \\
\hline Exports to the USA & 23.76 & 23.27 & 26.65 \\
\hline Imports from the EU25 & 19.31 & 15.46 & 19.94 \\
\hline Exports to the EU25 & 13.36 & 21.98 & 33.12 \\
\hline Imports from the Japan & 11.80 & 12.94 & 18.06 \\
\hline Exports to the Japan & 11.50 & 15.38 & 14.12 \\
\hline Imports from Southeast Asia & 5.76 & 24.42 & 29.86 \\
\hline Exports to Southeast Asia & 14.31 & 18.94 & 25.14 \\
\hline Imports from India & 11.34 & 33.61 & 40.10 \\
\hline Exports to India & 47.23 & 23.88 & 40.90 \\
\hline Imports from South America & 7.86 & 13.44 & 36.08 \\
\hline Exports to South America & 7.87 & 28.16 & 31.10 \\
\hline Imports from Africa & 3.03 & 25.67 & 40.51 \\
\hline Exports to Africa & 0.94 & 20.07 & 29.02 \\
\hline Imports from Transitional Economies & 43.32 & 1.51 & 24.61 \\
\hline Exports to Transitional Economies & 34.70 & 6.28 & 49.01 \\
\hline
\end{tabular}

\section{Appendix. Commodity Categories}

\section{Capital goods (except transport equipment, and parts and accessories thereof)}

Capital goods (except transport equipment)

Industrial Capital goods

Non-industrial

\section{Consumer durable goods (Transport equipment, and parts and accessories thereof)}

Passenger motor cars

Durable

Semi-durable

\section{Consumer non-durable goods}

Non-durable

Mainly for household consumption, consumption goods

\section{Intermediate goods}

Processed Intermediate goods 
Mainly for industry Intermediate goods

Mainly for industry Intermediate goods

Parts and accessories

Parts and accessories

\section{Primary Energy}

Primary Intermediate goods

Motor spirit

Other Capital goods (except transport equipment), and parts and accessories

\section{Primary Non-Energy}

Primary good

\section{Appendix: Country and County Groups}

\begin{tabular}{lll}
\hline South and South East Asian Country Group & Central \& South America Country Group & High-Income Asian Country Group \\
\hline Bangladesh & Argentina & Japan \\
Burundi & Barbados & South Korea \\
Cambodia & Bermuda & Taiwan \\
Sri Lanka & Bolivia & Singapore \\
Indonesia & Brazil & Malaysia \\
Nepal & Costa Rica & \\
Philippines & Cuba & Ocean Country Group \\
India & Dominica & Australia \\
Vietnam & Dominican Republic & New Zealand \\
Thailand & Ecuador & \\
Laos & El Salvador & Oil-Exporting Country Group \\
Pakistan & Guatemala & Bahrain \\
& Guyana & Canada \\
& Haiti & Iran \\
& Honduras & Iraq \\
& Jamaica & Kuwait \\
& Mexico & Oman \\
& Nicaragua & Nigeria \\
& Panama & Qatar \\
& Paraguay & Saudi Arabia \\
& Peru & Venezuela \\
& Antigua and Barbuda & Yemen \\
& Bahamas & \\
& Belize, Chile, Colombia & \\
& Grenada, Uruguay, Suriname & \\
& & \\
& & \\
& & \\
& & \\
& & \\
& & \\
& & \\
& & \\
& & \\
& & \\
& &
\end{tabular}

\begin{tabular}{ll}
\hline Transition Economies Country Group & European Union Country Group \\
\hline Albania & EU12- \\
Bulgaria & Austria \\
Croatia & Belgium \\
Czech Republic & Finland \\
FYR Macedonia & France \\
Hungary & Germany \\
Poland & Greece \\
Romania & Ireland \\
Slovak Republic & Italy \\
Slovenia & Luxembourg \\
Estonia & Netherlands \\
Latvia & Portugal \\
\hline
\end{tabular}




\begin{tabular}{ll}
\hline Lithuania & Spain \\
Armenia & EU15 \\
Azerbaijan & Austria \\
Belarus & Finland \\
Georgia & Sweden \\
Kazakhstan & EU25 \\
Kyrgyz Republic & Cyprus \\
Moldova & Czech Republic \\
Russia & Estonia \\
Tajikistan & Hungary \\
Turkmenistan & Latvia \\
Ukraine & Lithuania \\
Uzbekistan & Malta \\
Cambodia, Laos, Vietnam & Poland, Slovakia, Slovenia \\
\hline
\end{tabular}

\section{Copyrights}

Copyright for this article is retained by the author(s), with first publication rights granted to the journal.

This is an open-access article distributed under the terms and conditions of the Creative Commons Attribution license (http://creativecommons.org/licenses/by/4.0/). 